Document downloaded from:

http://hdl.handle.net/10251/111524

This paper must be cited as:

García-Segovia, P.; Pagán Moreno, MJ.; Lara, IF.; Martínez Monzó, J. (2017). Effect of microalgae incorporation on physicochemical and textural properties in wheat bread formulation. Food Science and Technology International. 23(5):437-447. doi:10.1177/1082013217700259

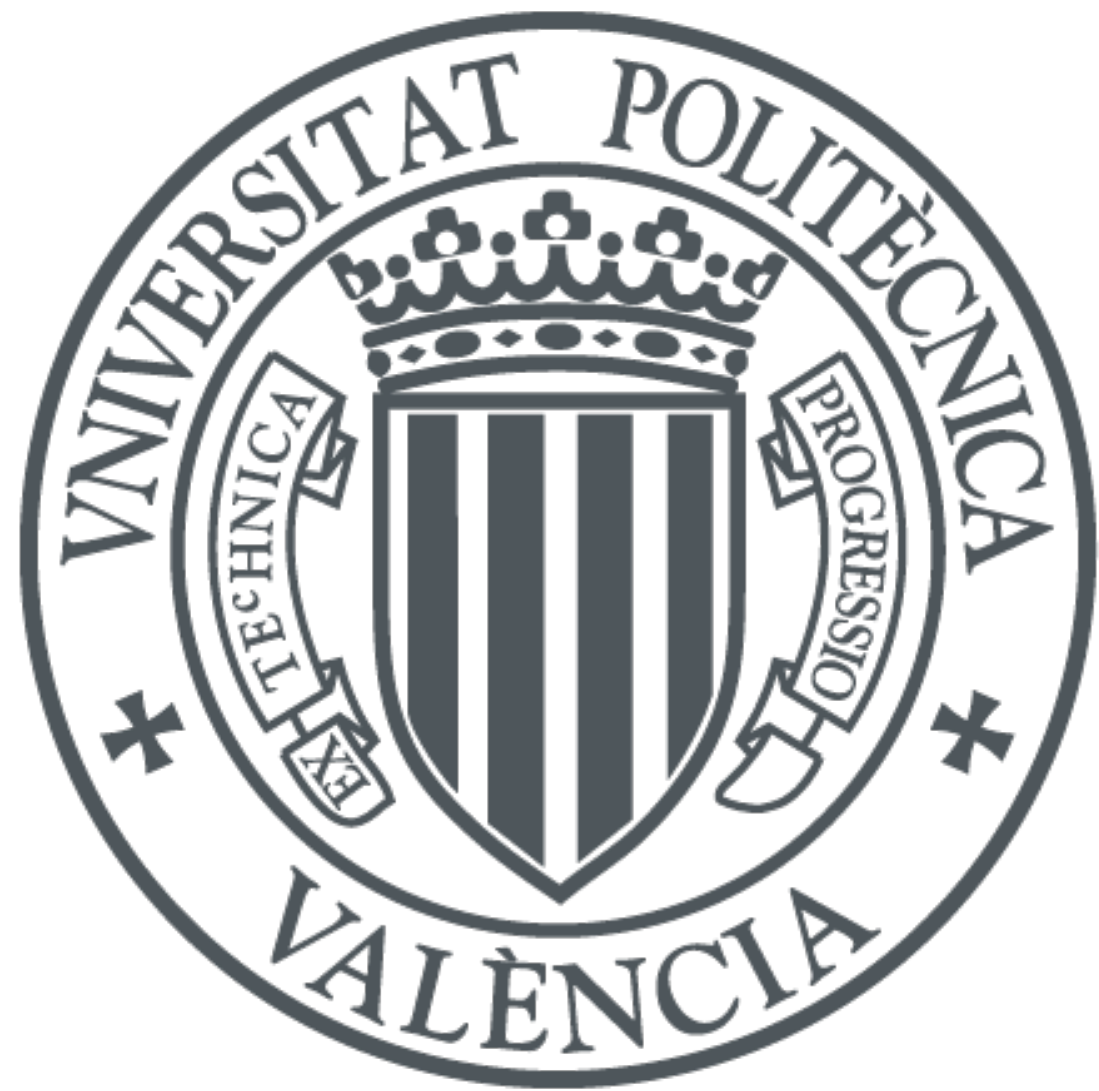

The final publication is available at

https://doi.org/10.1177/1082013217700259

Copyright SAGE Publications

Additional Information 


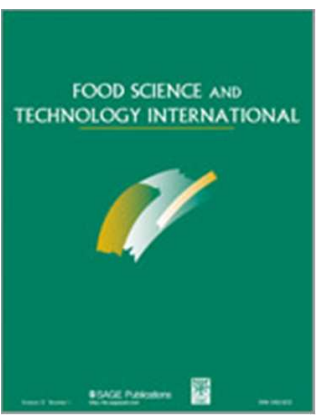

\section{Effect of microalgae incorporation on physico-chemical and textural properties in wheat bread formulation.}

\begin{tabular}{|c|c|}
\hline Journal: & Food Science and Technology International \\
\hline Manuscript ID & FSTI-16-0768.R2 \\
\hline Manuscript Type: & Research Article \\
\hline Subject category: & Physical, Chemical and Sensory Properties \\
\hline Date Submitted by the Author: & $\mathrm{n} / \mathrm{a}$ \\
\hline Complete List of Authors: & $\begin{array}{l}\text { García-Segovia, Purificación; Universitat Politècnica de València, Food } \\
\text { Technology Department } \\
\text { Pagán-Moreno, María ; Universitat Politècnica de València, Food Technology } \\
\text { Department } \\
\text { Lara, Irene; Universitat Politècnica de València, Food Technology } \\
\text { Department } \\
\text { Martinez Monzó, Javier; Universitat Politècnica de València, Food } \\
\text { Technology Department }\end{array}$ \\
\hline Keywords: & Algae, Breadmaking, Colour, Texture \\
\hline Abstract: & $\begin{array}{l}\text { The objective of this study was to evaluate the effect of the incorporation } \\
\text { of different micoalgae on physico-chemical and textural properties of } \\
\text { bread. Four species of microalgae Isochrysis galbana (Ig), Tetraselmis } \\
\text { suecica (Ts), Scenedesmus almeriensis (Sa) and Nannochloropsis gaditana } \\
(\mathrm{Ng}) \text { were used in this study. Properties as water activity, pH, } \\
\text { microbiological counts, viscosity and color were analyzed to determine the } \\
\text { effect of microalgae addition on sourdough. The technological quality of } \\
\text { breads was analyzed in terms of physico-chemical properties, color, texture } \\
\text { profile and porosity. The main effect of microalgae addition was changes in } \\
\text { bread color, crust and crumb that implies an increase of browning and an } \\
\text { evolution to more green-yellow tonalities. The textural parameters of } \\
\text { breads as hardness, chewiness and resilence are not modified by } \\
\text { microalgae addition. }\end{array}$ \\
\hline
\end{tabular}




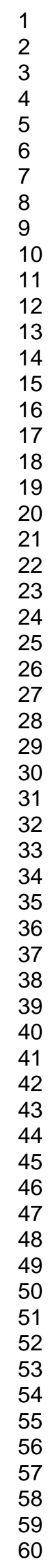

SCHOLARONE $^{\text {m }}$

Manuscripts

http://mc.manuscriptcentral.com/fsti 
1 Effect of microalgae incorporation on physico-chemical and textural properties in

2 wheat bread formulation.

3

4 P. García-Segovia ${ }^{\text {a }}$, J. Pagán-Moreno a , I.F. Lara ${ }^{\text {a }}$, J. Martínez-Monzó ${ }^{\text {a }}$.

$5 \quad{ }^{a}$ Food Technology Department, Universitat Politècnica de València, Camino de Vera

6 s/n., 46022 Valencia, Spain.

7

8 Corresponding author:

9 Javier Martínez-Monzó. Food Technology Department, Universitat Politècnica de

10 València, Camino de Vera s/n., 46022 Valencia, Spain.

11 Telf: 0034963877361

12 E-mail: xmartine@ tal.upv.es

13

14 FUNDING

15 This study has been carried out with own resources

16

17

18

19

http://mc.manuscriptcentral.com/fsti 
20 Effect of microalgae incorporation on physico-chemical and textural properties in

21 wheat bread formulation.

23 ABSTRACT

24 The objective of this study was to evaluate the effect of the incorporation of different 25 micoalgae on physico-chemical and textural properties of bread. Four species of 26 microalgae Isochrysis galbana (Ig), Tetraselmis suecica (Ts), Scenedesmus almeriensis 27 (Sa) and Nannochloropsis gaditana $(\mathrm{Ng})$ were used in this study. Properties as water 28 activity, $\mathrm{pH}$, microbiological counts, viscosity and color were analyzed to determine the 29 effect of microalgae addition on sourdough. The technological quality of breads was 30 analyzed in terms of physico-chemical properties, color, texture profile and porosity.

31 The main effect of microalgae addition was changes in bread color, crust and crumb that 32 implies an increase of browning and an evolution to more green-yellow tonalities. The 33 textural parameters of breads as hardness, chewiness and resilence are not modified by 34 microalgae addition.

Key words: microalgae, bread, color, texture 


\section{1. Introduction}

43 Bread is the most frequently consumed bakery product in many countries. In recent 44 years, different healthy ingredients have been used in the production of bread to 45 enhance its nutritional profile or to confer functional properties. Microalgae have 46 received increasing attention because they represent one of the most promising sources 47 of compounds with biological activity that could be used as functional ingredients 48 (Buono et al., 2014; Da Silva Vaz et al., 2016; Pulz and Gross, 2004). Their balanced 49 chemical composition (good quality proteins, balanced fatty acid profiles, vitamins, 50 antioxidants and minerals) and their interesting attributes can be applied in the 51 formulation of novel food products (Da Silva Vaz et al., 2016; Spolaore et al., 2006).

52 Microalgae are photosynthetic microorganisms with an important role as primary 53 producers in most aquatic food webs. They are characterized by a high diversity and are 54 potentially a great source of natural compounds for several biotechnological and 55 therapeutic applications (Borowitzka, 2013; Guedes et al., 2011; Raja et al., 2008). In 56 fact, they convert inorganic substances into organic matter richin lipids, proteins, 57 carbohydrates and other molecules. Because of their high nutritional value, microalgae 58 have been widely used in aquaculture as food for molluscs, zooplankton and early life59 stages of crustaceans and small fishes (Hemaiswarja et al., 2011). On the other hand, 60 microalgae are considered one of the prospective biological species for producing 61 biofuel (Brennan and Owende, 2010). Among microalgae, the species Isochrysis 62 galbana (I. galbana) is known to have good nutritional quality, and has received 63 increasing interest in aquaculture mainly due to its polyunsaturated fatty acid content 64 (Liu and Lin, 2001; Sánchez et al., 2000; Yoshioka et al., 2012). It also has beneficial 65 effects on human health and provides a good source of fish oil substitution in the human 66 diet (Batista et al., 2013; Yu et al., 2010). In addition, I. galbana showed promising 
67 curative effects inducing weight loss, decreased glucose, triacylglycerol and cholesterol

68 levels in diabetic rats (Nuño et al., 2013). Cultivation of I.galbana has also been 69 suggested for biodiesel production (Sánchez et al., 2013). Tetraselmis suecica (T. 70 suecica) is a marine based microalgae and is known to be able to tolerate salinity of 25 -

$7135 \%$. The microalgae species has a relatively high lipid concentration compared to other 72 microalgae species. Tolerance to high salinity, high specific growth rate and lipid 73 content of $T$. suecica makes it a good candidate for biofuel production (Zainan et al., 74 2015). The microalgae Scenedesmus almeriensis (S. almeriensis) was isolated in 75 Almería (Spain). Some remarkable characteristics of this species are its high lutein $76(0.53 \%$ dry mass $(\mathrm{DM}))$ and carotenoid $(0.69 \% \mathrm{DM})$ content, which make $S$. 77 almeriensis an interesting alternative for the production of carotenoids (Sánchez et al., 78 2008), the high productivity $\left(3.6 \mathrm{mg} \mathrm{L}^{-1}\right.$ day $\left.^{-1}\right)$, and its tolerance to a wide range of environmental growth conditions. From a nutritional point of view, furthermore, this 80 specie presents considerable protein content (49.4\% crude protein on DM basis) and a 81 fatty acid profile with substantial amounts of linolenic acid, 18:3n3 (Sánchez et al., 2008). The high protein content, together with remarkable productivity, turns $S$. almeriensis biomass into a potential protein ingredient. Nannochloropsis gaditana ( N. gaditana) is found in a wide range of temperature and irradiance conditions in natural environments, with high pigment contents (carotenoids), thus suggesting that this microalgae is able to regulate its photosynthetic apparatus as a function of culture 87 conditions (Camacho-Rodríguez et al., 2015; Lubián et al., 2000). Carotenoids have antioxidant properties and are therefore used in food and health preservation (Cerón et al., 2007). N. gaditana is also appreciated for its ability to accumulate proteins, lipids (Fábregas et al., 2002) and polyunsaturated fatty acids (PUFAs) (Camacho-Rodríguez et

91 al., 2015). The microalgae used in this work (Isochrysis galbana (Ig), Tetraselmis 
92 suecica (Ts), Scenedesmus almeriensis (Sa) and Nannochloropsis gaditana (Ng)) are

93 not recognized as GRAS at the moment.

94 Then, the use of natural ingredients as microalgae exhibiting functional properties, 95 providing specific health benefits, beyond traditional nutrients, is a very attractive way 96 to design new food products, with an important market niche of the healthier foods, 97 growing exponentially. One of the main issues regarding the application of functional 98 ingredients in novel food products is their stability and resistance to severe processing 99 conditions (e.g. high temperatures in bread production). So far, little research has been 100 carried out regarding the effects of whole microalgae incorporation in flour based 101 products. Gouveia et al. $(2007,2008)$ studied the use of Chlorella vulgaris as colouring 102 source in traditional butter cookies and the use of Isochrysis galbana as source of PUFA 103 in traditional biscuits. Rodríguez De Marco et al. (2014) use spirulina biomass to 104 enhance the nutritional profile of bread wheat pasta. Ketabi et al. (2008) analysed the 105 effect of microalgae exopolysaccharides in rheological properties of sourdoughs.

106 The aim of this work was to use four different microalgae biomass (I. galbana, T. 107 suecica, $S$. almeriensis and $N$. gaditana) as new functional ingredients to evaluate how 108 the addition of microalgae to bread dough affected the technological quality of this 109 product.

\section{2. Materials and methods}

\section{2.1. Materials}

112 Isochrysis galbana (Ig), Tetraselmis suecica (Ts), Scenedesmus almeriensis (Sa) and 113 Nannochloropsis gaditana $(\mathrm{Ng})$ used in this study (Fig. 1) were provided by 114 Universidad de Almeria (Department of Chemical Engineering, University of Almería, 115 Almería, Spain). The microalgae were obtained from the Marine Culture Collection of 
116 the Institute of Marine Sciences of Andalucía (CSIC, Cádiz, Spain) and produced in an

117 industrial size outdoor tubular photobioreactor, in continuous mode on Almería (Spain).

118 The biomass was daily harvested by centrifugation, then being freeze-drying and stored 119 at $18{ }^{\circ} \mathrm{C}$. The content of protein, carbohydrates and lipids $(\mathrm{P} / \mathrm{C} / \mathrm{L})$ in percentage for 120 freeze-dried microalgae used was 53 / 13.5 / 13 for Ig; 37.6 / 31.6 / 6.7 for Ts; 48.3 / $12138.3 / 10$ for $\mathrm{Sa}$ and 52 / 12 / 28 for Ng. Freeze-drying biomass was used as raw 122 material (Acién et al., 2012). The level considered of its use in sourdoughs was $1.5 \%$ to 123 obtain a final level of $0.6 \mathrm{~g}$ of microalgae in $150 \mathrm{~g}$ of bread. Chlorella vulgaris and 124 Arthrospira platensis (Spirulina) were taken as reference to define this level of use 125 because they are recognized as GRAS as an ingredient in food in a level of use of $1.35 \mathrm{~g}$ 126 (dairy intake) for Chlorella and 0.5 to $3 \mathrm{~g} / \mathrm{serving}$ for Spirulina (USFDA, 2011; 127 USFDA, 2012).

128 Wheat flour (Haricecu type H) was provided by Harinera Segorbina S.L. (Castellón, 129 Spain). The alveographic parameters were W $110 \pm 18$ and P/L $0.2 \pm 0.1$. Salted water 130 (Mediterranea Agua de Mar) was provided by Marevendis Agua de Mar S.L. (Alicante, 131 Spain). It is a commercial solution of purified and sterilized seawater with a 5\% salt 132 content $(86 \% \mathrm{NaCl}$ and $14 \%$ other minerals).

\section{2.2. Sourdough and bread preparation}

134 A local master baker (Horno San Bartolomé, Valencia, Spain) provided sourdough 135 starter. This starter was made with water and apple 50\% and flour $50 \%$ and 136 spontaneously fermented. Five sourdoughs were prepared, one without microalgae 137 (control) and four with $7.5 \mathrm{~g}$ of microalgae (Ig, $\mathrm{Ts}, \mathrm{Sa}$ or $\mathrm{Ng}$ ) added in $500 \mathrm{~g}$ of 138 sourdough starter $(1.5 \% \mathrm{w} / \mathrm{w})$. The mix was stored $24 \mathrm{~h}$ at $8{ }^{\circ} \mathrm{C}$ and $80 \%$ relative 139 humidity. Apart from the first fermentation, the operation named "back-slopping" (or 140 "refreshment"), consisting in the inoculation of flour and water with an aliquot of 
141 previously fermented dough, is repeated before each fermentation step (De Vuyst et al., 142 2009). After $24 \mathrm{~h}$, sourdoughs were tempered $2 \mathrm{~h}$ at $25^{\circ} \mathrm{C}$ and feed with water and flour 143 (15 g of both) to raise its activity. This mix was used to study the characteristics of 144 sourdough with microalgae. For bread elaboration, $40 \mathrm{~g}$ of each sourdough were mixed 145 with $100 \mathrm{~g}$ of wheat flour and $50 \mathrm{~g}$ of salted water with a spiral mixer (Kenwood Classic 146 Chef KM331, Kenwood Limited, New Lane, UK) during 10 min. This dough (190 g) 147 was shaped into loaves $(63 \mathrm{~g})$ and left to ferment at $9{ }^{\circ} \mathrm{C}$ during $20 \mathrm{~h}$ (slow 148 fermentation) at $75 \%$ relative humidity. After, doughs were maintained at room 149 temperature $\left(25^{\circ} \mathrm{C}\right)$ during $2 \mathrm{~h}$ and $75 \%$ relative humidity. Finally, the leavened 150 products were baked in rectangular molds ( $11 \mathrm{~cm}$ long, $6 \mathrm{~cm}$ wide, $3 \mathrm{~cm}$ height) at 210 $151{ }^{\circ} \mathrm{C}$ during $25 \mathrm{~min}$ in an oven steamer (Convotherm OES 6.06 mini $\mathrm{CC}$, Convotherm 152 Elektrogeräte GMBH, Eglfing, Germany) and cooled. Three breads for each 153 formulation were obtained with this process. The process was replicated as necessary to 154 obtain enough samples to analyze the different parameters considered in this study.

\section{2.3. Physico-chemical analysis}

156 The moisture content was determined by vacuum oven drying at $70{ }^{\circ} \mathrm{C}$ until constant 157 weight (AOAC, 1997). For determination of $\mathrm{pH}, 10 \mathrm{~g}$ of bread sample was 158 homogenized in $90 \mathrm{~mL}$ distilled water in the ratio 1:9 (w/v) using laboratory warring 159 blender. The measurement of $\mathrm{pH}$ in sourdough was made directly on a sample of 100 $160 \mathrm{~mL}$. The $\mathrm{pH}$ was measured using a Consort C830 pH-meter (Consort n.v. Parklaan, 161 Turnhout, Belgium) by inserting the electrode into the homogenates (AOAC, 1995). 162 Water activity was determined using an AquaLab Dewpoint Water Activity Meter 4TE 163 (Decagon Devices, Inc., Pullman, USA) (AOAC, 1998). Viscosity was measured with a 164 rotational viscometer Fungilab Alpha L Smart Series (Fungilab S.A., Barcelona, Spain) 165 and results were expressed in cP. Measurements were taken at $20^{\circ} \mathrm{C}$ using a spindle L4 
166 at constant rate of $12 \mathrm{rpm}$. Total titratable acidity (TTA) was determined using an 167 automatic titrator Metrohm 902 (Gomensoro S.A., Madrid, Spain) after homogenization 168 of $10 \mathrm{~g}$ of bread with $190 \mathrm{~mL}$ of distilled water, and expressed as the amount (mL) of $1690.1 \mathrm{M} \mathrm{NaOH}$ per gram of sample needed to reach the value of $\mathrm{pH}$ of 8.5. Samples were 170 analyzed by triplicate.

171 2.4. Microbiological analysis

172 Microbiological counts of fermented sourdoughs were determined. Ten grams of sample 173 were homogenized with $90 \mathrm{~mL}$ of sterile peptone water $(1 \%[\mathrm{w} / \mathrm{v}]$ of peptone and $0.9 \%$ $174[\mathrm{w} / \mathrm{v}]$ of $\mathrm{NaCl}$ ) solution. Total aerobic mesophilic bacteria (TAMB) counts were 175 determined using plate count agar (PCA, Scharlau, Barcelona, Spain), after incubating 176 for $48 \mathrm{~h}$ at $30^{\circ} \mathrm{C}$ (ISO, 2013). Lactic acid bacteria (LAB) were determined on De Man 177 Rogosa Sharpe (MRS) agar (Scharlau, Barcelona, Spain) after incubation at $30^{\circ} \mathrm{C}$ for $17848 \mathrm{~h}$ (ISO, 1998). Cell densities of yeasts and moulds were estimated on glucosed 179 Sabouraud medium (Scharlau, Barcelona, Spain) after incubation at $25^{\circ} \mathrm{C}$ for 5 days 180 (ISO, 1987).

181 2.5. Color

182 Color was measured using a Minolta CM3600d colorimeter (Minolta Corp., Ramsey, 183 NY, USA). The instrument was calibrated against a ceramic reference, illuminant C, 184 before use. Results were given in the CIELab system for illuminant D65 and a $10^{\circ}$ angle 185 of vision (CIE, 1986). Registered parameters were $L^{*}$ (brightness: $\mathrm{L}^{*}=0$ [black], L* = 186100 [white] $), a^{*}\left(-a^{*}=\right.$ greenness, $+a^{*}=$ redness $)$ and $b^{*}\left(-b^{*}=\right.$ blueness, $+b^{*}=$ 187 yellowness). Also for sourdough and breads, the total color difference $(\Delta \mathrm{E})$ between 188 samples with microalgae and control was calculated. For bread samples, the browning 189 index (BI) in crust and crumb was calculated.

$190 \quad \mathrm{BI}=[100(\mathrm{x}-0.31)] / 0.172$ 
191 Where:

$192 \mathrm{x}=\left(\mathrm{a}^{*}+1.75 \mathrm{~L}^{*}\right) /\left(5.654 \mathrm{~L}+\mathrm{a}^{*}-3.012 \mathrm{~b}^{*}\right)$

193 The browning index (BI) represents the purity of brown color and is reported as an 194 important parameter in processes where enzymatic or non-enzymatic browning takes 195 place (Palou et al., 1999)

196 For sourdough color four dough were measured in three different points for each 197 formulation. For crust and crumb color four breads of each formulation were measured 198 in three different points.

199 2.6. Textural properties

200 Texture Profile Analysis (TPA) was performed in bread slices (25 mm thin) without 201 crust using a TA-XTPlus Texture Analyser (Stable Micro Systems Ltd., Godalming, 202 UK) and software Texture Exponent Lite 32 (version 4.0.8.0). The samples were placed 203 on the base plate of the analyzer with a cylindrical aluminum probe (SMS P/75, $7.5 \mathrm{~cm}$ 204 in diameter) using a $50 \mathrm{~kg}$ load cell. The crosshead speed was $1.7 \mathrm{~mm} / \mathrm{s}$, with a rest 205 period of $15 \mathrm{~s}$ between cycles, and the deformation was $40 \%$ of the original length 206 (Jekle and Becker, 2012). Six textural parameters were determined from each curve: 207 hardness, adhesiveness, springiness, cohesiveness, chewiness and resilence (Bourne, 208 1978). Six different breads for each formulation were used.

209 2.7. Crumb porosity

210 Breads baked with different microalgae were cut into slices vertically. The slices were 211 placed over the glass of a scanner (HP Officejet 4636, USA) having a resolution of 300 212 dpi. The scanned image was analyzed using the software Image $\mathbf{J}$ 213 (http://rsb.info.nih.gov/ij/; Abramoff et al., 2004; Braadbaart and Van Bergen, 2005) 214 that uses the contrast between the two phases (pores and solid part) in the image. The 215 scanned color image is first converted to gray scale. Using bars of known lengths, pixel 
216 values are converted into distance units. The largest possible rectangular cross-section

217 of the bread slices was cropped. After adjusting the threshold, pore area as fraction of 218 total area was determined using the software (Datta et al., 2007). Six samples were 219 analyzed for each formulation.

\section{2.8. Statistical analysis}

221 The effect of the different treatments, on several variables was obtained by analysis of 222 variance, one-way ANOVA using the statistical package Statgraphics Centurion XVI 223 ver. 16.2.04 (StatPoint Technologies Inc., Virginia, USA). In those cases where the 224 effect was significant $(\mathrm{p}<0.05)$ the mean values were compared using Multiple Range 225 Tests and Fisher's least significant difference (LSD) procedure at 95\% confidence level $226(\mathrm{p}<0.05)$

\section{3. Results and discussion}

\section{3.1. Sourdough properties}

229 The initial value of $\mathrm{pH}$ for sourdough before fermentation was $4.35 \pm 0.02$. After $24 \mathrm{~h}$ at $2308{ }^{\circ} \mathrm{C}$, control sourdoughs showed values of $\mathrm{pH}$ of $3.72 \pm 0.02$ and $\mathrm{a}_{\mathrm{w}}$ values of $2310.9854 \pm .0006$ ) (Table 1). Compared to sourdough with microalgae, very slight 232 decreases $(\mathrm{p}<0.05)$ of the $\mathrm{a}_{\mathrm{w}}$ values occurred in samples with Ig, Sa and $\mathrm{Ng}$, and only in 233 sourdough with Ig a slight increase $(\mathrm{p}<0.05)$ of $\mathrm{pH}$ was detected $(0.1 \mathrm{pH}$ units $)$. The $\mathrm{pH}$ 234 values in the sourdoughs were similar those reported in other studies (Gül et al., 2005; 235 Şimşek et al., 2006).

236 Fig. 2 shows apparent viscosity of sourdoughs. In general, the addition of microalgae 237 increases viscosity of sourdough. The great increase was obtained with the addition of 238 Ig. Adesanya et al. (2012) studying rheological properties of microalgae for the 239 production of biofuels showed that even at low concentrations microalgae interaction 
240 plays a role in terms of viscosity enhancement. This is an effect to take into account

241 because an excessive increase of viscosity in the sourdough can affect the characteristics

242 of foam structure in the dough.

243 The results of the microbiological counts of the sourdoughs are reported in Fig. 3. The 244 total bacterial counts of the samples showed significant differences $(\mathrm{p}<0.05)$ and 245 ranged from $1.5 \times 10^{7} \mathrm{CFU} / \mathrm{g}$ (control) to $6.3 \times 10^{7} \mathrm{CFU} / \mathrm{g}(\mathrm{Sa})$. These results indicated a 246 lighter increase of TAMB in the samples with microalgae. However, levels of TAMB 247 were similar that observed in other studies (Gül et al., 2005; M'hir et al., 2007; Şimşek 248 et al., 2006). Moulds and yeast counts showed significant differences $(\mathrm{p}<0.05)$ between 249 the different samples analyzed. The reached values oscillated between $5.0 \times 10^{6} \mathrm{CFU} / \mathrm{g}$ 250 for sourdoughs with $\mathrm{Ng}$ to $7.9 \times 10^{6} \mathrm{CFU} / \mathrm{g}$ for control and samples with Ig. Similar 251 counts of these microorganisms have been show in others studies (Gül et al., 2005; 252 Şimşek et al., 2006). The values of LAB counts ranged between $3.9 \times 10^{8} \mathrm{CFU} / \mathrm{g}$ to 1.0 $253 \times 10^{9} \mathrm{CFU} / \mathrm{g}$ and the sourdoughs with Ts and Sa showed higher values of LAB counts. 254 As a rule, $\mathrm{LAB}$ is the predominant microorganisms and in many cases, yeasts are 255 present in significant numbers (Vogel et al., 1999; Vogel et al., 1996). LAB and yeasts 256 are often associated in sourdough. The LAB/yeasts ratio generally varied between 10:1 257 and 100:1 (Gobbetti et al., 1994; Ottogalli et al., 1996; Pepe et al., 2004). In this study, 258 the ratio was between 100/0.63 in the samples with Ts and Sa and 100/2 with control. In 259 the case of samples with $\mathrm{Ng}$ this relation was $100 / 1$. It is generally considered that the 260 optimal ratio should be about 100:1 for optimal leavening and acidification activities 261 (Rehman et al., 2006).

262 In good bakery practice, the levels of LAB and yeasts should be of $10^{8} \mathrm{CFU} / \mathrm{g}$ to $10^{9}$ $263 \mathrm{CFU} / \mathrm{g}$ and $10^{6} \mathrm{CFU} / \mathrm{g}$ to $10^{7} \mathrm{CFU} / \mathrm{g}$ for acidification and leavening action of dough, 264 respectively (De Vuyst and Neysens, 2005; Rehman et al., 2006). 
265 The incubation of sourdough at low temperature $\left(8^{\circ} \mathrm{C}\right)$ can significantly limit the 266 growth of many LAB species (De Vuyst and Neysens, 2005; Rizello et al., 2016).

267 Furthermore, as already observed (Corsetti and Settanni, 2007), the ratio between yeast 268 and LAB populations in sourdough is greatly affected by temperature. Changes in color 269 are the most significant effect of microalgae addition in sourdoughs. The analysis of $\mathrm{L}^{*}$ 270 (Table 1) shows that lightness decreased significantly $(\mathrm{p}<0.05)$ with microalgae 271 addition, which means that the addition of microalgae biomass resulted in darker 272 sourdoughs. However, differences $(\mathrm{p}<0.05)$ are found between microalgae been $\mathrm{Ng}$ the 273 ones that provide more light sourdoughs and Ts and Sa the ones that provide more dark 274 samples. The evaluation of $\mathrm{a}^{*}$ parameter shows that microalgae, except Ts, significantly $275(\mathrm{p}<0.05)$ increase the sourdoughs green color (negative $\mathrm{a}^{\star}$ values) and the yellow 276 tonality $\left(\mathrm{b}^{\star}\right)($ Table 1$)$. The $\Delta \mathrm{E}$ values show perceivable color differences $(\Delta \mathrm{E}>3)$ with 277 control for all sourdoughs with microalgae. In spite of that, the addition of the 278 microalgae to the sourdough implies darker sourdough with an increase of yellow-green 279 tonality.

280 3.2. Physico-chemical properties of bread

281 After baking at $210{ }^{\circ} \mathrm{C}$ during $25 \mathrm{~min}$, control doughs presented aw values of $2820.9492 \pm 0.0051$, moisture of $33 \pm 1 \%$ and $\mathrm{pH}$ of $10.2 \pm 0.2$, corresponding to values of 283 TTA of $5.4 \pm 0.4 \mathrm{~mL} 0.1 \mathrm{M} \mathrm{NaOH} / 10 \mathrm{~g}$ of dough (Table 2). Compared to breads with 284 microalgae there are few differences between samples. The final aw values and TTA 285 were similar for all samples only small differences were obtained for moisture and $\mathrm{pH}$ 286 values. That means that the addition of microalgae in the levels studied in this work not 287 implies a significant change on physicochemical properties of bread. 
289 The variation in the crumb and crust color parameters of the breads due to the addition 290 of microalgae are summarized in Table 3 . In the same way than for sourdough, $\Delta \mathrm{E}$ 291 values show perceivable color differences in crust and crumb with control for all breads 292 with microalgae. A $\Delta \mathrm{E}>3$ implies perceivable color difference for a consumer (Witzel et 293 al., 1973). The crust color parameters showed a decrease in whiteness ( $\left.L^{*}\right)$ and a 294 statistically significant increase in browning index (BI) with the addition of microalgae. 295 Crust color depends on the physico-chemical characteristics of the raw dough (i.e. water 296 content, $\mathrm{pH}$, reducing sugars and amino acid content), ingredients of the dough and on 297 the operating conditions applied during baking (i.e. temperature, air speed, relative 298 humidity, heat transfer conditions) (Purlis and Salvadori, 2007; Zanoni et al., 1995). 299 Crust browning is due to caramelization and Maillard reactions, belonging to the non300 enzymatic or non-oxidative browning category (Fennema, 1996). In this case, 301 degradation of microalgae pigments as chlorophyll and carotenoids due to heat also 302 contribute to color changes in samples with microalgae. The samples with lower values 303 of $\mathrm{L}^{*}$ were breads with Sa, followed by Ig and Ts and finally with $\mathrm{Ng}$. This differences 304 can be explained by the different pigment concentration in microalgae (Bai et al., 2011), 305 when higher pigment concentration more changes occurs. Parameter a* (redness) and $306 \mathrm{~b}^{*}$ (yellowness) showed significant differences $(\mathrm{p}<0.05)$. In general addition of 307 microalgae implies a decrease of $\mathrm{a}^{*}$ (redness) and an increase of $\mathrm{b}^{*}$ (yellowness), except 308 for breads with Ts in which $\mathrm{a}^{*}$ increase, this effect was the same observed in the 309 sourdough. This can be due to the high quantity of carotenoids that are present in these 310 microalgae (Garrido and Rodríguez, 2009). The addition of microalgae produces 311 changes in crust color that implies increase of browning index and an evolution to more 312 green-yellow tonalities. Related to changes in crumb color, addition of microalgae 313 caused a statistically significant $(\mathrm{p}<0.05)$ decrease in whiteness $\left(\mathrm{L}^{*}\right)$, redness $\left(\mathrm{a}^{*}\right)$ and 
314 an increase in yellowness of crumb compared to the control sample. These changes are 315 related, as in the case of the crust, with the content of pigments in microalgae. Sa is 316 characterized by its high lutein content, up to 0.53\% DM (Sánchez et al., 2008). In this 317 case the addition of Sa implies an increase of $b^{*}$ (yellowness) in crust and crumb. Ig is 318 rich in chlorophyll a (Valenzuela-Espinoza et al., 2002) that implies lower values of a* 319 (greenness) and an increase of $\mathrm{b}^{*}$ (yellowness). $\mathrm{Ng}$ is a source of $\beta$-carotene and 320 vaucheriaxanthin (Camacho-Rodríguez et al., 2015).

\subsection{Structural properties of bread}

322

323

324

325

326

327

328

329

330

331

332

333

334

335

336

337

Table 4 shows the crumb textural properties of bread prepared from different microalgae obtained from TPA test. The textural parameters of breads suggested that the structure was not largely affected by the incorporation of microalgae. With respect to crumb properties, hardness, chewiness and resilence are not modified by microalgae addition $(\mathrm{p}<0.05)$. Adhesiveness increase and springiness decrease in samples with Ig and cohesiveness decrease in samples with $\mathrm{Ng}$.

Crumb cohesiveness reflects internal cohesion of the material. Bread with high cohesiveness is desirable because it forms a bolus, rather than disintegrates during mastication whereas low cohesiveness indicates increased susceptibility of the bread to fracture or crumble. Crumb elasticity is described by springiness and resilience (Bourne, 2002). A reduction in resilience or springiness characterizes loss of elasticity. Resilience is defined as the ratio of the area under the curve of the second half of the first cycle (upward stroke) to the first half (downward stroke) (Moore et al., 2004). On the other hand, springiness refers to the distance that the food recovers its height during the time that elapses between the end of the first bite (or compression) and the start of the second bite (Bourne, 2002). Since springiness is time-dependent, its value is dependent on the 
338 time interval between the compression cycles. It is therefore obvious that breads can 339 recover their springiness completely (i.e. 100\%) if the time interval between the 340 compression cycles is sufficiently long. However, this point of view is irrelevant under 341 practical conditions because an adult makes about 1 chew s$^{-1}$ (Bourne, 2002), which is 342 considerably lower than the $5 \mathrm{~s}$ used in our Texture Profile Analysis study. Changes in 343 crumb chewiness reflected the changes in firmness, cohesiveness and springiness 344 because chewiness is a product of the three texture parameters (Bourne, 2002). Crumb 345 chewiness reflects the energy required to masticate food to a state ready for swallowing. 346 Chewy foods tend to remain in the mouth without rapidly breaking up or dissolving 347 (Bourne, 2002). Adhesiveness is not a desired crumb attribute because its sensory 348 equivalent is an undesirable moist and sticky crumb.

349 Crumb porosity of different breads with microalgae and control is shown in Fig. 4. The 350 obtained values of porosity were $16 \pm 5 \%$ for Is, $19 \pm 3 \%$ for Ts, $18 \pm 4 \%$ for Sa, $14 \pm 1 \%$ 351 for $\mathrm{Ng}$ and $12 \pm 4 \%$ for control samples. There is no significant change in porosity $352(\mathrm{p}<0.05)$ comparing with the control porosity measured as percentage of surface space 353 occupied by holes by surface unit. Porosity is caused by the production of the $\mathrm{CO}_{2}$ gas 354 by yeast and some heterofermentative lactic acid bacteria. The $\mathrm{CO}_{2}$ content increases 355 during fermentation as the $\mathrm{pH}$ drops (Farnworth, 2003). In the samples with microalgae 356 the gas was released as the same way than in control samples.

\section{Conclusions}

Microalgae represents a new ingredient in bread formulation as source of important 360 natural compounds for human nutrition. Under conditions used in this study, their 361 incorporation in bread formulation did not modify significantly physico-chemical 
362 properties or microbiological counts of the sourdough. In general addition of microalgae 363 implies changes in color of bread related with a decrease of $\mathrm{a}^{*}$ (redness) and an increase 364 of $b^{*}$ (yellowness). These changes are related with the content of pigments in 365 microalgae. The textural parameters of breads as hardness, chewiness and resilence are 366 not modified by microalgae addition.

\section{Acknowledgments}

368 We thank Jesús Machi for their technical assistance with bread formulation. J. Martínez369 Monzó, P. García-Segovia and M.J. Pagan-Moreno designed the experiments and 370 discussed the results; I.F. Lara and P. García-Segovia performed the experiments and 371 summarised the results; J. Martínez-Monzó, P. García-Segovia, M.J. Pagán-Moreno and 372 I.F. Lara contributed to analysis and interpretation of data, drafting the article and 373 revising it. The authors declare no conflict of interest.

\section{$375 \quad$ References}

376 A.O.A.C. Association of Official Analytical Chemists. (1995). Official Methods of 377 Analysis. (16th ed.). Washingtong, DC.

378 A.O.A.C. Association of Official Analytical Chemists. (1997). Official Methods of 379 Analysis. Washington, DC.

380 A.O.A.C. Association of Official Analytical Chemists. (1998). Official Methods of 381 Analysis. Washington, DC.

382 Abramoff MD, Magelhaes PJ and Ram SJ. (2004). Image processing with imageJ. 383 Biophotonics International 11(7): 36-42. 
384 Acién FG, Fernández JM, Magán JJ and Molina E. (2012). Production cost of a real 385 microalgae production plant and strategies to reduce it. Biotechnology Advances 30: $386 \quad 1344-1353$.

387 Adesanya VO, Vadillo DC and Mackley MR. (2012). The rheological characterization 388 of algae suspensions for the production of bioguels. Journal of Rheology 56: 925-939.

389 Bai M-D, Cheng C-H, Wan H-M and Lin Y-H. (2011). Microalgal pigments potential as 390 byproducts in lipid production. Journal of the Taiwan Institute of Chemical Engineers $391 \quad 42: 783-786$.

392 Batista AP, Gouveia L, Bandarra-Narcisa M, Franco JM and Raymundo A. 393 (2013).Comparison of microalgal biomass profiles as novel functional ingredient for 394 food products. Algal Research 2: 164-173.

395 Borowitzka MA. (2013). High-value products from microalgae, their development and 396 commercialization. Journal of Applied Phycology 25: 743-756.

397 Bourne M. (2002). Food texture and viscosity. Concept and measurement. New York, 398 USA: Academic Press, Elsevier Science.

399 Bourne MC. (1978). Texture Profile Analysis. Food Technology 32: 62- 66.

400 Buono S, Langellotti AL, Martello A, Rinna F and Fogliano V. (2014). Functional 401 ingredients from microalgae. Food \& Function 8: 1669-1685.

402 Braadbaart F and Van Bergen PF. (2005). Digital imaging analysis of size and shape of 403 wheat and pea upon heating under anoxic conditions as a function of the temperature. 404 Vegetation History and Archaeobotany 14: 67-75. 
405 Brennan L and Owende P. (2010). Biofuels from microalgae. A review of technologies

406 for production, processing, and extractions of biofuels and co-products. Renewable and

407 Sustainable Energy Reviews 14: 557-577.

408 Camacho-Rodríguez J, Cerón-García MC, Fernández-Sevilla JM and Molina-Grima E.

409 (2015). The influence of culture conditions on biomass and high value product

410 generation by Nannochloropsis gaditana in aquaculture. Algal Research 11: 63-73.

411 Cerón MC, García-Malea MC, Rivas J, Acién FG, Fernández JM, Del Río E, Guerrero

412 MG and Molina E. (2007). Antioxidant activity of Haematococcus pluvialis cells grown

413 in continuous culture as a function of their carotenoid and fatty acid content. Applied

414 Microbiology Biotechnology 74: 1112-1119.

415 CIE (Commission Internationale de l'Eclairage) (1986) Colorimetry: technical report.

416 2nd edn, CIE Pub. No.15. Pp. 35-36. Vienna, Austria.

417 Corsetti A and Settanni L. (2007). Lactobacilli in sourdough fermentation. Food $418 \quad$ Research International 40: 539-558.

419 Da Silva Vaz B, Moreira JB, Morais MG and Costa JAV. (2016). Microalgae as a new 420 source of bioactive compounds in food supplements. Current Opinion in Food Science $421 \quad 7: 73-77$.

422 Datta AK, Sahin S, Sumnu G and Keskin O. (2007). Porous media characterization of 423 breads baked using novel heating modes. Journal of Food Engineering 79: 106-116.

424 De Vuyst D and Neysens P. (2005). The sourdough microflora: biodiversity and 425 metabolic interactions. Trends in Food Science and Technology 16: 43-56. 
426 De Vuyst L, Vrancken G, Ravyts F, Rimaux T, Weckx S. (2009). Biodiversity, 427 ecological determinants, and metabolic exploitation of sourdough microbiota. Food 428 Microbiology 26: 666-675.

429 Fábregas J, Maseda A, Domínguez A, Ferreira M and Otero A. (2002). Changes in the 430 cell composition of the marine microalga, Nannochloropsis gaditana, during a 431 light:dark cycle. Biotechnology Letters 24: 1699-1703.

432 Farnworth ER. (2003). Handbook of fermented functional foods. Boca Raton, FL: CRC.

433 Fennema OR. (1996). Food chemistry (3rd ed.). New York: Marcel Dekker.

434 Garrido JL and Rodríguez F. (2009). Occurrence of loroxanthin, loroxanthin decenoate, 435 and loroxanthin dodecenoate in Tetraselmis species (Prasinophyceae, Chlorophyta). 436 Journal of Phycology 45: 366-374.

437 Gobbetti M, Corsetti J, Rossi F, La Rosa F and De Vicenzi S. (1994). Identification and 438 clustering of lactic acid bacteria and yeasts from wheat sourdoughs of central Italy. 439 Italian Journal of Food Science 1: 85-94.

440 Gouveia L, Batista AP, Sousa I, Miranda A, Empis J and Raymundo A. (2007). 441 Chlorella vulgaris biomass used as colouring source in traditional butter cookies. 442 Innovative Food Science and Emerging Technologies 8: 433-436.

443 Gouveia L, Coutinho C, Mendonça E, Batista AP, Sousa I, Bandarra NM and 444 Raymundo A. (2008). Sweet biscuits with Isochrysis galbana microalga biomass as a 445 functional ingredient. Journal of the Science of Food and Agriculture 88: 891-896. 
446 Guedes AC, Amaro HM and Malcata FX. (2013). Microalgae as sources of high added-

447 value compounds. A brief review of recent work. Biotechnology Progress 27(3): 597448613.

449 Gül H, Özçelik S, Sağdiç O and Certel M. (2005). Sourdough bread production with 450 lactobacilli and S. cerevisiae isolated from sourdoughs. Process Biochemistry 40: 691451697.

452 Hemaiswarja S, Raja R, Kumar RR, Ganesan V and Anbazhagan C. (2011). 453 Microalgae: A sustainable feed source for aquaculture. World Journal of Microbiology 454 and Biotechnology 27: 1737-1746.

455 International Standards Organization - ISO (1998). Microbiology of food and animal 456 feeding stuffs - Horizontal method for the enumeration of mesophilic lactic acid 457 bacteria - Colony-count technique at $30^{\circ} \mathrm{C}$, ISO 15214. Geneva, Switzerland: The 458 International Organization for Standardization.

459 International Standards Organization- ISO (2013). Microbiology of the food chain, 460 Horizontal method for the enumeration of microorganisms, Part 1: Colony count at 30 $461{ }^{\circ} \mathrm{C}$ by the pour plate technique, ISO 4833-1. Geneva, Switzerland: The International 462 Organization for Standardization.

463 International Standards Organization- ISO (1987). Microbiology: General guidance for 464 enumeration of yeasts and moulds: Colony count technique at $25^{\circ} \mathrm{C}$, ISO 7954. Geneva, 465 Switzerland: The International Organization for Standardization.

466 Jekle M and Becker T. (2012). Effects of acidification, sodium chloride, and moisture 467 levels on wheat dough: II. Modeling of bread texture and staling kinetics. Food 468 Biophysics 7: 200-208. 
469 Ketabi A, Soleimannian-Zad S, Kadivar M and Sheikh-Zeinoddin, S. (2008).

470 Production of microbial exopolysaccharides in the sourdough and its effects on the

471 rheological properties of dough. Food Research International 41: 948-951.

472 Liu CP and Lin LP. (2001). Ultrastructural study and lipid formation of Isochrysis sp.

473 CCMP1324. Botanical Bulletin of Academia Sinica 42: 207-214.

474 Lubián LM, Montero O, Moreno-Garrido I, Huertas IE, Sobrino C, González-del Valle

475 M and Parés G. (2000). Nannochloropsis (Eustigmatophyceae) as source of 476 commercially valuable pigments. Journal of Applied Phycology 12: 249-255.

477 M'hir S, Mejri M and Hamdi M. (2007). Microflora distribution and species ratio of 478 Tunisian fermented doughs for bakery industry. African Journal of Biotechnology 479 6(18): 2122-2129.

480 Moore MM, Schober T, Dockery P and Arendt EK. (2004). Textural comparisons of 481 gluten-free and wheat-based doughs, batters and breads. Cereal Chemistry 81: 567-575.

482 Nuño K, Villarruel-López A, Puebla-Pérez AM, Romero-Velardec E, Puebla-Morad 483 AG and Ascencio F. (2013). Effects of the marine microalgae Isochrysis galbana and 484 Nannochloropsis oculata in diabetic rats. Journal of Functional Foods 5: 106-115.

485 Ottogalli G, Galli A and Foschino R. (1996). Italian bakery products obtained with 486 sourdough: characterization of the typical microflora. Advances in Food Science 18: $487 \quad 131-144$.

488 Palou E, López-Malo A, Barbosa-Cánovas GV, Welti-Chanes J and Swanson BG. 489 (1999). Polyphenoloxidase activity and color of blanched and high hydrostatic pressure 490 treated banana puree. Journal of Food Science 64: 42-45. 
491 Pepe O, Blaiotta G, Anastasio M, Moschetti G, Ercolini D and Villani F. (2004).

492 Technological and molecular diversity of Lactobacillus plantarum strains isolated from 493 naturally fermented sourdoughs. Systematic and Applied Microbiology 27: 443-453.

494 Pulz O and Gross W. (2004). Valuable products from biotechnology of microalgae. 495 Applied Microbiology and Biotechnology 65: 635-648.

496 Purlis E and Salvadori VO. (2007). Bread browning kinetics during baking. Journal of 497 Food Engineering 80: 1107-1115.

498 Raja R, Hemaiswarya S, Kumar NA, Sridhar S and Rengasamy R. (2008). A 499 perspective on the biotechnological potential of microalgae. Critical Reviews in $500 \quad$ Microbiology 34: 77-88.

501 Rehman SR, Paterson A and Piggott JR. (2006). Flavour in sour dough breads: a 502 review. Trends in Food Science and Technology 17: 557-566.

503 Rizello CG, Lorusso A, Montemurro M and Gobbetti M. (2016). Use of sourdough 504 made with quinoa (Chenopodium quinoa) flour and autochthonous selected lactic acid 505 bacteria for enhancing the nutritional, textural and sensory features of white bread. Food 506 Microbiology 56: 1-13.

507 Rodríguez De Marco E, Steffolani ME, Martínez CS and León AE. (2014). Effects of 508 spirulina biomass on the technological and nutritional quality of bread wheat pasta. 509 LWT-Food Science and Technology 58(1): 102-108.

510 Sánchez A, Maceiras R, Cancela A and Pérez A. (2013). Culture aspects of Isochrysis 511 galbana for biodiesel production. Applied Energy 10: 192-197. 
512 Sánchez JF, Fernández JM, Acién FG, Rueda A, Pérez-Parra J and Molina E. (2008).

513 Influence of culture conditions on the productivity and lutein content of the new strain

$514 \quad$ Scenedesmus almeriensis. Process Biochemistry 43: 398-405.

515 Sánchez S, Martínez ME and Espinola F. (2000). Biomass production and biochemical 516 variability of the marine microalga Isochrysis galbana in relation to culture medium.

517 Biochemical Engineering Journal 6: 13-18.

518 Şimşek Ö, Çon AH and Tulumoğlu Ş. (2006). Isolating lactic starter cultures with 519 antimicrobial activity for sourdough processes. Food Control 17: 263-270.

520 Spolaore P, Joannis-Cassan C, Duran E and Isambert A. (2006). Commercial 521 applications of microalgae. Journal of Bioscience and Bioengineering 101(2): 87-96.

522 USFDA. (2011). Agency response letter GRAS notice no. GRN 000391. [online] 523 http://www.fda.gov/Food/IngredientsPackagingLabeling/GRAS/NoticeInventory/ucm3 $524 \quad$ 01318.htm (last accessed on June 8, 2016).

525 USFDA. (2012). Agency response letter GRAS notice no. GRN 000396. [online] 526 http://www.fda.gov/Food/IngredientsPackagingLabeling/GRAS/NoticeInventory/ucm3 $527 \quad 20210$. htm (last accessed on June 8, 2016).

528 Valenzuela-Espinoza E, Millán-Núñez R and Núñez-Cebrero F. (2002). Protein, 529 carbohydrate, lipid and chlorophyll a content in Isochrysis aff. galbana (clone T-Iso) 530 cultured with a low cost alternative to the f/2 medium. Aquacultural Engineering 25: $531 \quad 207-216$.

532 Vogel RF, Knorr R, Müller MRA, Steudel U, Gänzle MG and Ehrmann MA. (1999). 533 Non-dairy lactic fermentations: the cereal world. Antonie van Leeuwenhoek 76: 403534411. 
535 Vogel RF, Müller M, Stolz P and Ehrmann M. (1996). Ecology in sourdoughs produced 536 by traditional and modern technologies. Advances in Food Science 18: 152-159.

537 Witzel RF, Burnham RW and Onley JW (1973). Threshold and suprathreshold 538 perceptual color differences. Journal of Optical Society of America 63: 615-625.

539 Yoshioka M, Yago T, Yoshie-Stark Y, Arakawa H and Morinaga T. (2012). Effectof 540 high frequency of intermittent light on the growth and fatty acid profile of Isochrysis 541 galbana. Aquaculture 338-341: 111-117.

542 Yu CC, Chen HW, Chen MJ, Chang YC, Chien SC, Kuo YH, Yang FL, Wu SH, Chen 543 J, Yu HH and Chao LK. (2010).Chemical composition and bioactivities of the marine 544 alga Isochrysis galbana from Taiwan. Natural Product Communications 5: 1941-1944.

545 Zainan NH, Srivatsa SC and Bhattacharya S. (2015). Catalytic pyrolysis of microalgae 546 Tetraselmis suecica and characterization study using in situ Synchrotron-based Infrared 547 Microscopy. Fuel 161: 345-354.

548 Zanoni B, Peri C and Bruno D. (1995). Modelling of browning kinetics of bread crust 549 during baking. LWT-Food Science and Technology 28(3): 604-609. 
Table 1. Sourdough CIE $\mathrm{L}^{*} \mathrm{a} * \mathrm{~b} *$ coordinates, total difference of color $(\Delta \mathrm{E}), \mathrm{a}_{\mathrm{w}}$ and $\mathrm{pH}$ values for samples with microalgae; Isochrysis galbana (Ig), Tetraselmis suecica (Ts), Scenedesmus almeriensis $(\mathrm{Sa})$ and Nannochloropsis gaditana $(\mathrm{Ng})$ and control. Lightness $\left(\mathrm{L}^{*}\right)$, green-red chromaticity (a*), blue-yellow chromaticity ( $\mathrm{b}^{*}$ ) (Medium values of twelve replicates for color parameters and three replicates for $\mathrm{a}_{\mathrm{w}}$ and $\mathrm{pH}$ ).

\begin{tabular}{ccccccc}
\hline Sample & $\mathrm{L}^{*}$ & $\mathrm{a}^{*}$ & $\mathrm{~b}^{*}$ & $\Delta \mathrm{E}$ & $\mathrm{a}_{\mathrm{w}}$ & $\mathrm{pH}$ \\
\hline $\mathrm{Ig}$ & $59 \pm 1^{\mathrm{b}}$ & $-2.36 \pm 0.08^{\mathrm{a}}$ & $19.0 \pm 0.3^{\mathrm{c}}$ & $18.9 \pm 0.7^{\mathrm{b}}$ & $0.9803 \pm 0.0009^{\mathrm{a}}$ & $3.80 \pm 0.01^{\mathrm{b}}$ \\
$\mathrm{Ts}$ & $56 \pm 1^{\mathrm{a}}$ & $0.85 \pm 0.14^{\mathrm{d}}$ & $16.4 \pm 0.7^{\mathrm{b}}$ & $20.4 \pm 0.9^{\mathrm{c}}$ & $0.9837 \pm 0.0011^{\mathrm{bc}}$ & $3.74 \pm 0.02^{\mathrm{a}}$ \\
$\mathrm{Sa}$ & $56 \pm 1^{\mathrm{a}}$ & $-2.41 \pm 0.07^{\mathrm{a}}$ & $21.4 \pm 0.8^{\mathrm{d}}$ & $23.0 \pm 0.8^{\mathrm{d}}$ & $0.9823 \pm 0.0019^{\mathrm{ab}}$ & $3.74 \pm 0.06^{\mathrm{a}}$ \\
$\mathrm{Ng}$ & $64 \pm 1^{\mathrm{c}}$ & $-0.94 \pm 0.08^{\mathrm{b}}$ & $16.9 \pm 0.6^{\mathrm{b}}$ & $13.6 \pm 1.0^{\mathrm{a}}$ & $0.9804 \pm 0.0010^{\mathrm{a}}$ & $3.72 \pm 0.01^{\mathrm{a}}$ \\
Control & $76.3 \pm 0.9^{\mathrm{d}}$ & $-0.61 \pm 0.04^{\mathrm{c}}$ & $10.3 \pm 0.1^{\mathrm{a}}$ & - & $0.9854 \pm 0.0006^{\mathrm{c}}$ & $3.72 \pm 0.02^{\mathrm{a}}$ \\
\hline
\end{tabular}

Note: superscript characters (letters) indicate the effect of microalgae addition. Values in the same column for each formulation with the same letter are not statistically different according to the Tukey test $(\mathrm{p}<0.05)$. 
Table 2. Bread $\mathrm{a}_{\mathrm{w}}$, moisture, $\mathrm{pH}$ and total titratable acidity (TTA) values for samples with microalgae; Isochrysis galbana (Ig), Tetraselmis suecica (Ts), Scenedesmus almeriensis (Sa) and Nannochloropsis gaditana $(\mathrm{Ng})$ and control (Medium values of three replicates).

\begin{tabular}{ccccc}
\hline Sample & $\mathrm{a}_{\mathrm{w}}$ & $\begin{array}{c}\text { Moisture } \\
(\%)\end{array}$ & $\mathrm{pH}$ & $\begin{array}{c}\mathrm{TTA} \\
(\mathrm{mL} / 10 \mathrm{~g})\end{array}$ \\
\hline $\mathrm{Ig}$ & $0.9518 \pm 0.0007^{\mathrm{a}}$ & $31 \pm 2^{\mathrm{a}}$ & $10.1 \pm 0.1^{\mathrm{a}}$ & $5.3 \pm 0.1^{\mathrm{a}}$ \\
$\mathrm{Ts}$ & $0.9513 \pm 0.0038^{\mathrm{a}}$ & $33.5 \pm 0.8^{\mathrm{ab}}$ & $10.3 \pm 0.1^{\mathrm{ab}}$ & $5.1 \pm 0.2^{\mathrm{a}}$ \\
$\mathrm{Sa}$ & $0.9532 \pm 0.0028^{\mathrm{a}}$ & $34 \pm 2^{\mathrm{ab}}$ & $10.17 \pm 0.07^{\mathrm{a}}$ & $5.0 \pm 0.3^{\mathrm{a}}$ \\
$\mathrm{Ng}$ & $0.9528 \pm 0.0030^{\mathrm{a}}$ & $35 \pm 1^{\mathrm{b}}$ & $10.5 \pm 0.1^{\mathrm{b}}$ & $5.1 \pm 0.6^{\mathrm{a}}$ \\
Control & $0.9492 \pm 0.0051^{\mathrm{a}}$ & $33 \pm 1^{\mathrm{ab}}$ & $10.2 \pm 0.2^{\mathrm{a}}$ & $5.4 \pm 0.4^{\mathrm{a}}$ \\
\hline
\end{tabular}

Note: superscript characters (letters) indicate the effect of microalgae addition. Values in the same column for each formulation with the same letter are not statistically different according to the Tukey test $(\mathrm{p}<0.05)$. 
Table 3. Browning index (BI), total difference of color $(\Delta \mathrm{E})$ and CIE $\mathrm{L}^{*} \mathrm{a} \mathrm{b}^{*}$ coordinates for crust and crumb bread samples with microalgae; Isochrysis galbana (Ig), Tetraselmis suecica (Ts), Scenedesmus almeriensis (Sa) and Nannochloropsis gaditana $(\mathrm{Ng})$ and control. Lightness $\left(\mathrm{L}^{*}\right)$, green-red chromaticity $\left(\mathrm{a}^{*}\right)$, blue-yellow chromaticity $\left(\mathrm{b}^{*}\right)$ (Medium values of twelve replicates).

\begin{tabular}{cccccc}
\hline Crust & $\mathrm{L}^{*}$ & $\mathrm{a}^{*}$ & $\mathrm{~b}^{*}$ & $\Delta \mathrm{E}$ & $\mathrm{BI}$ \\
\hline $\mathrm{Ig}$ & $64 \pm 2^{\mathrm{c}}$ & $0.93 \pm 0.39^{\mathrm{a}}$ & $27 \pm 1^{\mathrm{c}}$ & $9 \pm 2^{\mathrm{b}}$ & $53 \pm 4^{\mathrm{c}}$ \\
$\mathrm{Ts}$ & $62 \pm 1^{\mathrm{b}}$ & $3.08 \pm 0.40^{\mathrm{d}}$ & $24 \pm 1^{\mathrm{b}}$ & $11 \pm 1^{\mathrm{c}}$ & $53 \pm 5^{\mathrm{c}}$ \\
$\mathrm{Sa}$ & $59 \pm 1^{\mathrm{a}}$ & $0.87 \pm 0.23^{\mathrm{a}}$ & $28 \pm 1^{\mathrm{d}}$ & $15 \pm 1^{\mathrm{d}}$ & $64 \pm 4^{\mathrm{d}}$ \\
$\mathrm{Ng}$ & $66 \pm 1^{\mathrm{d}}$ & $1.53 \pm 0.32^{\mathrm{b}}$ & $23 \pm 1^{\mathrm{a}}$ & $7 \pm 1^{\mathrm{a}}$ & $44 \pm 3^{\mathrm{b}}$ \\
Control & $73.2 \pm 0.7^{\mathrm{e}}$ & $2.72 \pm 0.40^{\mathrm{c}}$ & $23 \pm 1^{\mathrm{a}}$ & - & $39 \pm 3^{\mathrm{a}}$ \\
\hline Crumb & $\mathrm{L}^{*}$ & $\mathrm{a}^{*}$ & $\mathrm{~b}^{*}$ & $\Delta \mathrm{E}$ & $\mathrm{BI}$ \\
\hline $\mathrm{Ig}$ & $70 \pm 1^{\mathrm{b}}$ & $0.06 \pm 0.18^{\mathrm{a}}$ & $20.4 \pm 0.8^{\mathrm{d}}$ & $8 \pm 1^{\mathrm{b}}$ & $33 \pm 2^{\mathrm{c}}$ \\
$\mathrm{Ts}$ & $69 \pm 1^{\mathrm{b}}$ & $1.80 \pm 0.16^{\mathrm{d}}$ & $19.6 \pm 0.7^{\mathrm{c}}$ & $8 \pm 1^{\mathrm{b}}$ & $33 \pm 2^{\mathrm{c}}$ \\
$\mathrm{Sa}$ & $67 \pm 2^{\mathrm{a}}$ & $0.21 \pm 0.16^{\mathrm{b}}$ & $23 \pm 1^{\mathrm{e}}$ & $12 \pm 2^{\mathrm{c}}$ & $40 \pm 5^{\mathrm{d}}$ \\
$\mathrm{Ng}$ & $73 \pm 1^{\mathrm{c}}$ & $0.62 \pm 0.17^{\mathrm{c}}$ & $18.4 \pm 0.7^{\mathrm{b}}$ & $4 \pm 1^{\mathrm{a}}$ & $29 \pm 2^{\mathrm{b}}$ \\
Control & $77 \pm 1^{\mathrm{d}}$ & $1.96 \pm 0.18^{\mathrm{e}}$ & $16.8 \pm 0.6^{\mathrm{a}}$ & - & $26 \pm 1^{\mathrm{a}}$
\end{tabular}

Note: superscript characters (letters) indicate the effect of microalgae addition. Values in the same column for each formulation with the same letter are not statistically different according to the Tukey test $(\mathrm{p}<0.05)$. 
2

Table 4. Crumb texture profile parameters of bread with microalgae; Isochrysis galbana (Ig), Tetraselmis suecica (Ts), Scenedesmus almeriensis (Sa) and Nannochloropsis gaditana (Ng) and control (Medium values of six replicates).

\begin{tabular}{|c|c|c|c|c|c|c|}
\hline & $\begin{array}{l}\text { Hardness } \\
(\mathrm{N})\end{array}$ & $\begin{array}{c}\text { Adhesiveness } \\
(\mathrm{N} \mathrm{s})\end{array}$ & Cohesiveness & Springiness & $\begin{array}{l}\text { Chewiness } \\
(\mathrm{N})\end{array}$ & Resilence \\
\hline Ig & $311 \pm 51^{\mathrm{a}}$ & $-0.52 \pm 0.32^{\mathrm{a}}$ & $0.65 \pm 0.01^{\mathrm{ab}}$ & $0.93 \pm 0.00^{\mathrm{a}}$ & $187 \pm 30^{\mathrm{a}}$ & $0.32 \pm 0.01^{\mathrm{a}}$ \\
\hline Ts & $313 \pm 6^{\mathrm{a}}$ & $-0.29 \pm 0.26^{\mathrm{ab}}$ & $0.66 \pm 0.01^{\mathrm{ab}}$ & $0.94 \pm 0.00^{\mathrm{ab}}$ & $194 \pm 6^{\mathrm{a}}$ & $0.34 \pm 0.01^{\mathrm{a}}$ \\
\hline $\mathrm{Sa}$ & $320 \pm 22^{a}$ & $-0.13 \pm 0.16^{b}$ & $0.66 \pm 0.01^{\mathrm{ab}}$ & $0.94 \pm 0.00^{\mathrm{b}}$ & $199 \pm 17^{a}$ & $0.34 \pm 0.01^{\mathrm{a}}$ \\
\hline $\mathrm{Ng}$ & $313 \pm 43^{\mathrm{a}}$ & $-0.09 \pm 0.09^{b}$ & $0.64 \pm 0.02^{\mathrm{a}}$ & $0.94 \pm 0.00^{\mathrm{ab}}$ & $187 \pm 29^{a}$ & $0.33 \pm 0.01^{\mathrm{a}}$ \\
\hline Control & $299 \pm 21^{\mathrm{a}}$ & $-0.09 \pm 0.08^{\mathrm{b}}$ & $0.72 \pm 0.10^{\mathrm{b}}$ & $0.94 \pm 0.02^{\mathrm{ab}}$ & $202 \pm 20^{\mathrm{a}}$ & $0.37 \pm 0.06^{\mathrm{a}}$ \\
\hline
\end{tabular}


Fig. 1. Micrographs of microalgae used. (a) Isochrysis galbana (Ig), (b) Tetraselmis suecica (Ts), (c) Scenedesmus almeriensis (Sa) and (d) Nannochloropsis gaditana (Ng).

Fig. 2. Sourdough viscosity of samples with different microalgae. Isochrysis galbana (Ig), Tetraselmis suecica (Ts), Scenedesmus almeriensis (Sa) and Nannochloropsis gaditana $(\mathrm{Ng})$.

Fig. 3. Microbiological counts of the sourdoughs. Isochrysis galbana (Ig), Tetraselmis suecica (Ts), Scenedesmus almeriensis ( $\mathrm{Sa}$ ) and Nannochloropsis gaditana (Ng). Superscript characters (letters) indicate the effect of microalgae addition in each parameter, the same letter are not statistically different according to the Tukey test ( $\mathrm{p}<$ $0.05)$.

Fig. 4. Crumb porosity of different breads with microalgae. (a) Isochrysis galbana (Ig), (b) Tetraselmis suecica (Ts), (c) Scenedesmus almeriensis (Sa), (d) Nannochloropsis gaditana $(\mathrm{Ng})$ and (e) control. 

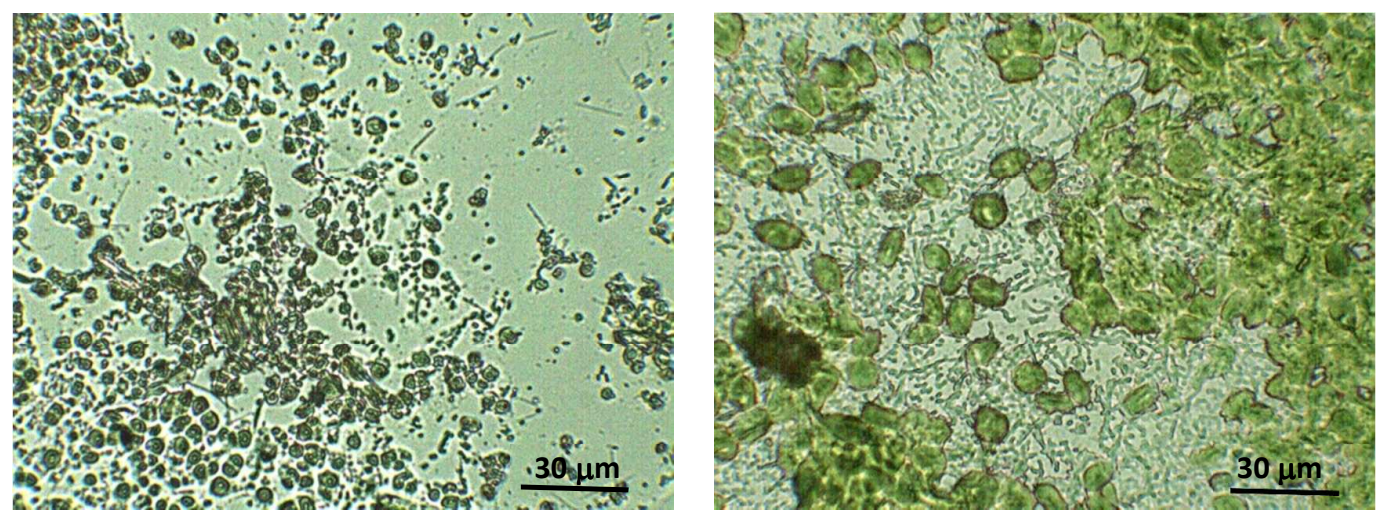

(a)

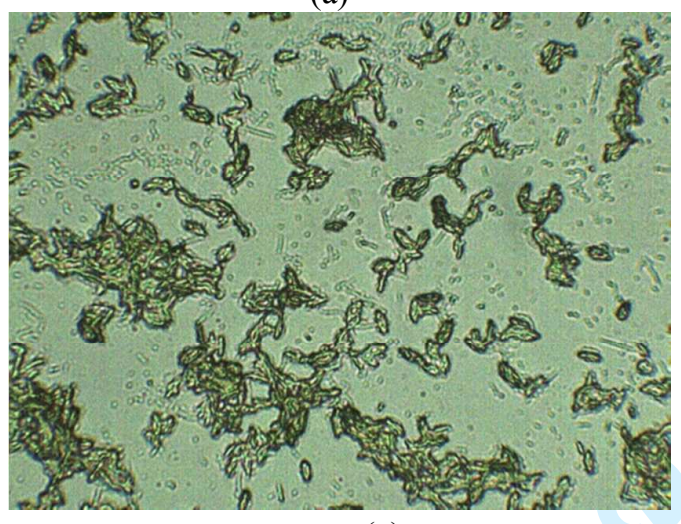

(c) (b)

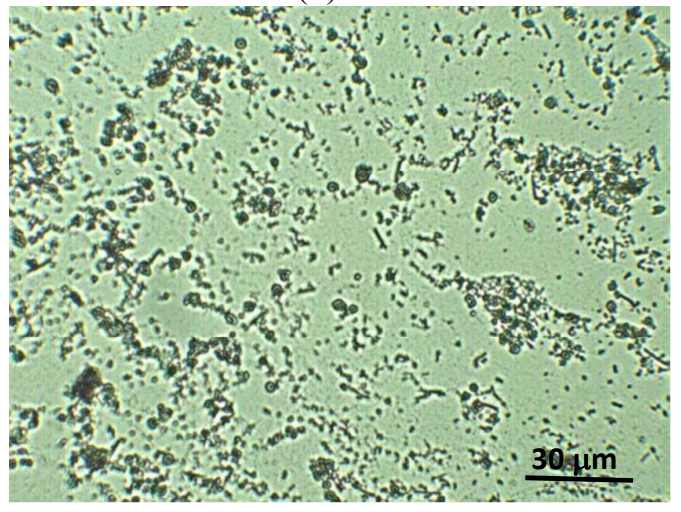

(d)

Fig.1 


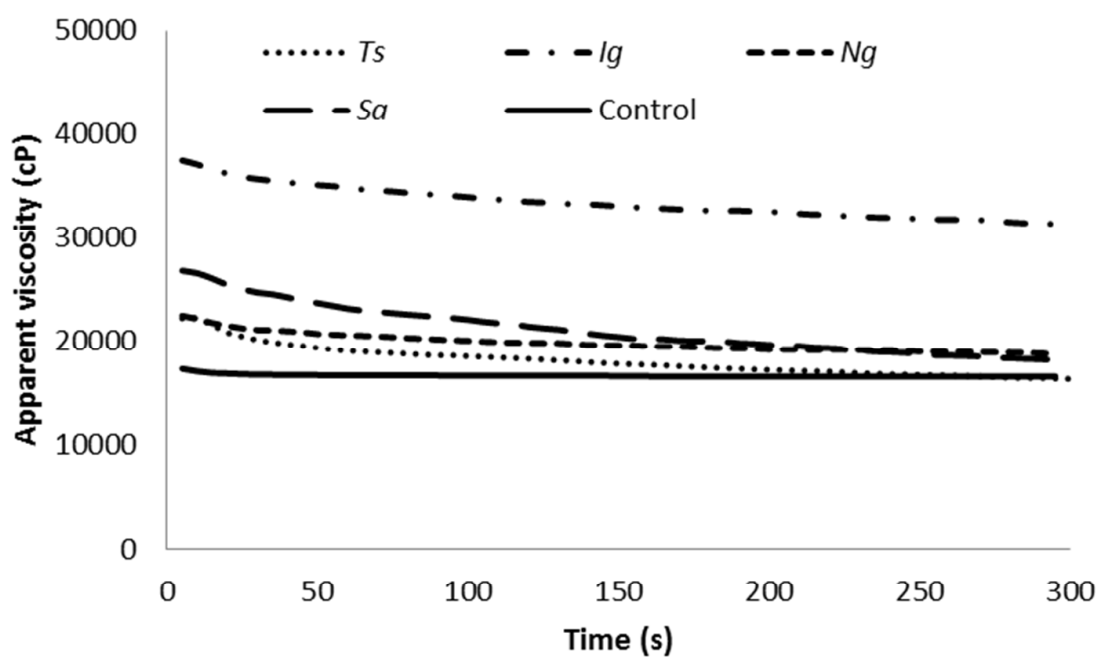

Fig. 2 


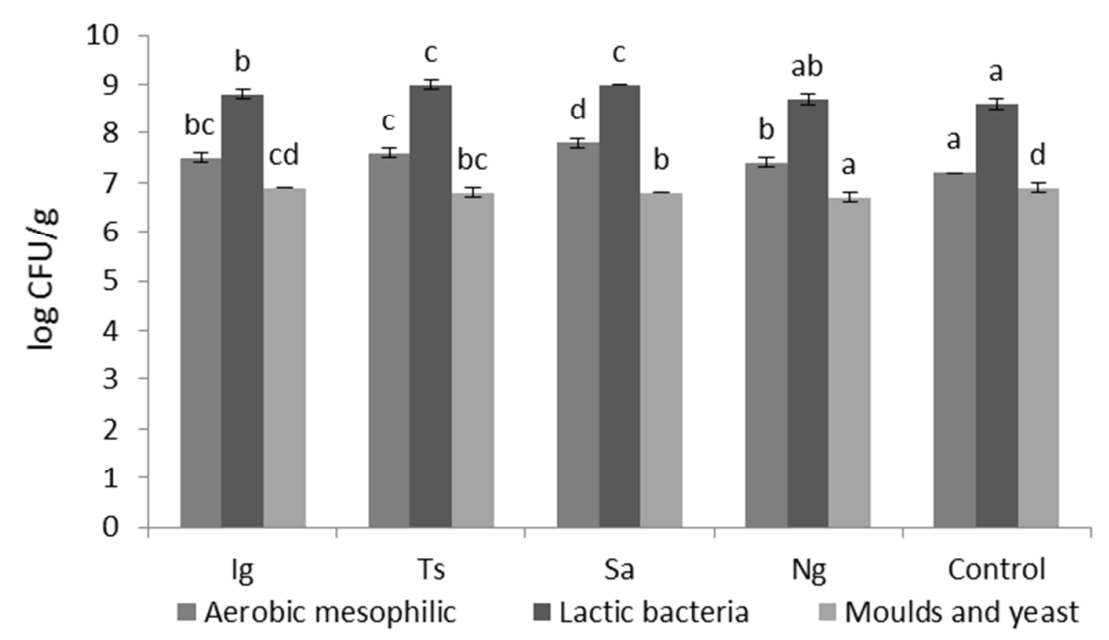

Fig. 3 


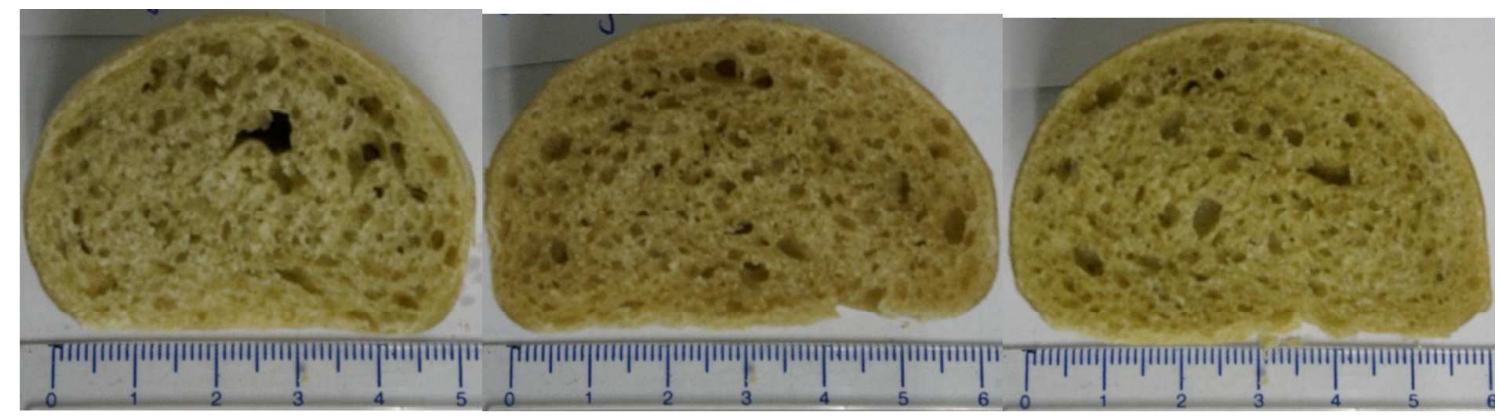

(a)

(b)

(c)

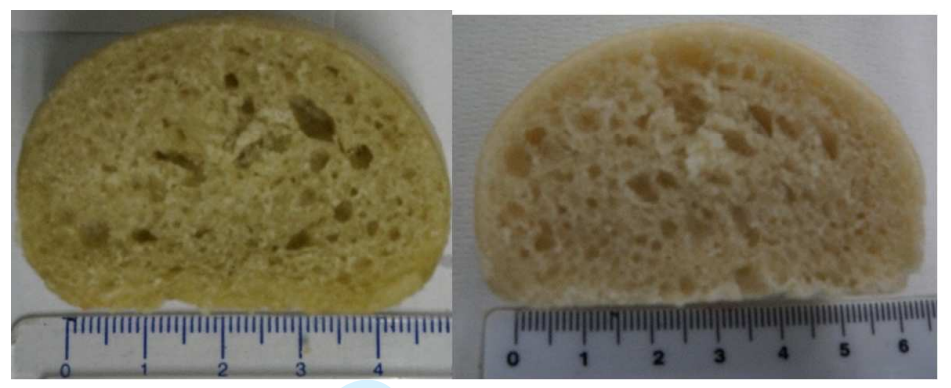

(d)

(e)

Fig. 4 